\title{
DIE INVLOED VAN TOEKOMSTENDENSE OP ENTREPRENEURS EN KLEINSAKEONDERNEMINGS
}

\author{
J.J.D. Havenga \\ Fakulteit Ekonomiese en Bestuurswetenskappe \\ Potchefstroomse Universiteit vir $\mathrm{CHO}$ \\ POTCHEFSTROOM
}

\begin{abstract}
John Naisbitt is the author of three academic publications on futurology. In this article a comparison of these publications of the last decade is made with regard to the ten postulates stated in each book. The core of each postulate is abstracted and its relation to the future development of various aspects affecting man and the world in which he functions is indicated. The contents of Naisbitt's works is condensed and divided into four main categories covering technology, economics, cultural/social issues, management and organisation. In each of these subdivisions an attempt is made to outline the practical applicability of facets of these main categories. With this approach the particular characteristics (strong and weak points) which may transform present implications into new opportunities can more easily be indicated.
\end{abstract}

\section{INLEIDING}

Dit blyk dat die term futurist eers gedurende die sestigerjare deel van die Engelse taal geword het toe dit in tydskrifte in die VSA begin verskyn het. Heelwat later het die term sy verskyning gemak in die Afrikaanse taal en wel in die term futuroloog. Hierdie benaming is onder andere gekoppel aan persone soos prof. P. Spies van die Stellenbosse Universiteit en prof. C.H. Boshoff van die Potchefstroomse Universiteit wat met hul onderskeie institute toekomstendense probeer aandui. In die sakewêreld is daar ook die alombekende Clem Sunter van die Anglo American-groep. Baie futuroloë verkies egter teenswoordig om na hulle self te verwys as langtermynbeplanners, vooruitskatters, sosiale teoretici, tendensanaliste en toekomskundiges (Coates \& Jarrat, 1989:vii).

Die terreine waarop hulle hulself begeef of die komponente van toekomsstudie kan in ses groepe verdeel word: strukturele elemente, onderliggende oorsake, stimulante en inhibeerders van verandering, primêre akteurs, instansies en stelsels, gebeurtenisse en ideale alternatiewe en opkomende gemeenskappe (Coates \& Jarrat, 1989:28-41). Hieronder word aspekte soos die volgende behandel: sektorale ekonomieë en gemeenskappe, wêreld-ekonomie, tegnologie, omgewing, wetenskap, waardes en hou- 
dings, politieke faktore, innovasie, konflikterende gemeenskapsdryfvere, informasie, energie, geloof en 'n verskeidenheid ander elemente.

Dit is opvallend dat beskouings oor die toekoms meesal op 'n makro-vlak geskied en dat daar nie sonder meer beweeg word na die mikro-elemente nie. So byvoorbeeld word daar na die ekonomie met al sy elemente in die breë gekyk, maar nie spesifiek aandag gegee aan byvoorbeeld die entrepeneur of kleinsakeonodernemining en waar hy in die toekoms gaan inpas nie. Verder is baie van die bydraes gebaseer op ontwikkelings in die VSA, die Pacific Rim (Japan, Taiwan, Indonesië, Australië en die westelike deel van die VSA) en Europa.

\section{AGTERGROND EN DOEL}

John Naisbitt het as futuroloog wêreldwye roem verwerf met sy boek Megatrends: Ten new directions transforming our lives (1982) en dit opgevolg met die boeke Re-inventing the corporation (Naisbitt \& Aburdene, 1985) en Megatrends 2000: Ten new directions for the 1990's (Naisbitt \& Aburdene, 1990). Om die doel van die artikel beter te verstaan, is dit noodsaaklik dat daar eerstens aandag gegee word aan kernaspekte van sy geskrifte.

Deur in sy eerste boek (1982) gebruik te maak van 'n metodologie gebaseer op 'n vergelykende inhoudsanalise van 6000 plaaslike koerante ten opsigte van plaaslike gebeure oor 'n aantal jare, kom Naisbitt tot die gevolgtrekking dat die mens getuie is van 'n belangrike verandering in ekonomiese en sosiale waardes. Die herstrukturering van die VSA is alreeds besig om die mens se innerlike en uiterlike lewe te verander. As 'n gemeenskap het die mens van die oue na die nuwe beweeg.

'n Inherente deel van hierdie stellings is die gedagte dat 'n beslissende verskuiwing in die wêreldmag besig is om plaas te vind namate die wêreldmag van 'n industriële tot ' $n$ inligtingsgemeenskap getransformeer word (Naisbitt, 1982:1).

In die tweede boek gaan die skrywer verder met die analise deur te fokus op die onderneming, sy funksionering en bestuur. Hierdie analise lè klem daarop dat die ongewone gelcentheid wat die afgelope dekade meegebring het, benut moet word. Jou werk en onderneming moet naamlik omskep word in ooreenstemming met die nuwe behoefte van die nuwe inligtingsgemeenskap (Naisbitt \& Aburdene,1985:1).

In sy derde boek is Naisbitt se uitgangspunt (1990:11) dat die mens voor die mees belangrike dekade in die geskiedenis van die beskawing staan, naamlik 'n periode van verstommende tegnologiese innovasie, onvergelykbare ekonomiese geleenthede, ver- 
rassende politieke hervorming en 'n groot kulturele wedergeboorte. Op grond van hierdie afleidings word gepoog om die belangrikste tendense vir die negentigerjare te identifiseer en te beskryf.

Waar die eerste boek grotendeels klem gelê het op tendense wat die VSA beïnvloed het, lê die jongste een meer klem op Noord-Amerika, Europa en die Pacific Rim. Hierdie benaderingswyse is waarskynlik gevolg veral omdat inligtingstegnologieë, diens en elektronika hierdie streke verenig.

Die vraag kan gestel word of enige lesse geleer kan word uit hierdie bydraes van Naisbitt wat relatief breed is en grotendeels gebaseer is op die VSA en Europa en of daar enige relevansie vir Suid-Afrika is en meer spesifiek, die entrepreneurs en kleinsakeondernemings van dié gebied.

In 'n poging om hierdie vrae te beantwoord, sal die doel van hierdie artikel gevolglik wees om in 'n samevattende vorm die belangrikste stellings van Naisbitt weer te gee en om dan sekere afleidings te makk met betrekking tot entrepreneurs en kleinsakeondernemings in Suid-Afrika.

Voortvloeiend uit die bestudering van enkele literatuurbronne is die metodiek wat gevolg is basies konsepsueel van aard. Eerstens is 'n kruis-korrelasie van die stellings in die verskillende boeke gemaak en dit word in tabel 1 weergegee. Deur 'n kritiese analise van die stellings te maak, kon die stellings tot vier duidelike kategorieë gereduseer word vanwaar toepassings op entrepreneurskap en kleinsakebestuur gemaak kan word (vgl. tabel 2).

\section{DIE BELANGRIKSTE STELIINGS VAN NAISBITT}

Omdat die werke van Naisbitt omvattend is, word die stellings kortliks bespreek. Alhoewel meer beredenering daarvan wenslik is, word volstaan met 'n kernagtige samevatting van die inhoud van elke stelling wat Naisbitt se siening verteenwoordig.

\subsection{Die tien mega-tendense (Megatrends, 1982)}

In die eerste boek, Megatrends : Ten new directions transforming our lives (1982) word daar tien mega-tendense bespreek wat 'n invloed op die wêreld het, en die veranderinge wat dit tot gevolg het. 


\subsubsection{Die verandering van 'n industriële na 'n inligtingsgemeenskap}

Hierdie is ' $n$ belangrike verandering wat terugdateer vanaf 1956 toe kantoorwerkers vir die eerste keer in die Amerikaanse geskiedenis in tegniese, bestuurs- en klerklike posisies meer was as die handearbeiders. Op die huidige stadium word massas inligting geproduseer op dieselfde wyse waarop die massa-produksie van motors vroeër plaasgevind het. Hierdie mega-tendens wys heen na beslissende veranderinge in tegnologieë: nie alleen wys dit heen na die inwerking van data-prosessering en die toepassing van programmatuur in industriële prosesse nie, maar ook na die vooruitgang van nuwe tegnologieë soos die elektronika, biotegnologie, laser en selfs die aanwending van nuwe materiale.

\subsubsection{Die verandering vanaf gedwonge tegnologie na hoë tegnologie}

Alhoewel die konsep nie heeltemal duidelik is nie, verwys dit grotendeels na die behoefte aan 'n menslike reaksie wat die instelling van nuwe tegnologie sal kontrabalanseer, en wat aanleiding sal gee tot die opkoms van hoë persoonlike waardesisteme om sodoende te kompenseer vir die onpersoonlike aard van tegnologie. 'n Uitvloeisel van hierdie konsep word byvoorbeeld weerspieël in die tendens om die onpersoonlikheid van werksomgewing te verander: so word sagte kleure en nie-uniformiteit in styl en mode aangewend om 'n meer 'genaakbare' werkomgewing daar te stel.

\subsubsection{Die verandering vanaf 'n nasionale ekonomie na 'n wêreldekonomie}

Hierdie aspek het betrekking op die internasionalisering van beleggings en handel, en tot 'n sekere mate op eenvormige wêreld-ekonomiese beleidsrigtings, onder andere ten opsigte van die aanwending van arbeid, optredes van vakbonde, eenvormige geldstelsels en gestandaardiseerde pryse.

\subsubsection{Die verandering vanaf korttermyn- tot langtermynbeplanning}

Ondernemings moet in reaksie op versnellende veranderinge in tegnieke, produkte en markte voortdurend herbesin ten opsigte van die aard van die onderneming waarin hulle hul bevind om sodoende nuwe strategiese visies daar te kan stel en te implementeer. 
TENDENSE EN STELLINGS - JOHN NAISBITT

\begin{tabular}{|c|c|c|}
\hline Megatrends - 1982 & Re-Inventing the corporation - 1985 & Megatrends $2000-1990$ \\
\hline I. Industrizle tot informasiegemeenskap & $\begin{array}{l}\text { 1. Die verskuiwing in strate- } \\
\text { giese bronne van ' } n \text { industrizle na 'n } \\
\text { informasiegemeenskap }\end{array}$ & $\begin{array}{l}\text { 1. Die opkomende wereldekonomie } \\
\text { van die negentigerjare }\end{array}$ \\
\hline $\begin{array}{l}\text { 2. Geforseerde tegnologie tot hot } \\
\text { tegnologie (High tech/high louch) }\end{array}$ & $\begin{array}{l}\text { 2. 'n Verkopersmark en die auwe } \\
\text { mededinging vir die beste werknemers }\end{array}$ & 2. 'o Renaissance in die kunste \\
\hline $\begin{array}{l}\text { 3. Nasionale ekonomie tot wereld- } \\
\text { ekonomie }\end{array}$ & 3. Die inkorting van middelbestuur & 3. Die groei van die vryemarksosialisme \\
\hline 4. Kort termyn tot lang termyn & $\begin{array}{l}\text { 4. Die kontinuerende entrepreneuriese } \\
\text { revolusie }\end{array}$ & $\begin{array}{l}\text { 4. Wereldlewenstyle en kulturele nasiona- } \\
\text { lisme }\end{array}$ \\
\hline 5. Sentralisasie tot desentralisasie & $\begin{array}{l}\text { 5. Die opkoms van die nuwe varierende } \\
\text { arbeidsmag }\end{array}$ & 5. Privatisering van die welveartstaat \\
\hline 6. Institusionele hulp tot selfhulp & $\begin{array}{l}\text { 6. Die demografiese revolusie van } \\
\text { werkende vrouens }\end{array}$ & 6. Die groei van die Pacific Rim \\
\hline $\begin{array}{l}\text { 7. Verteenwoordigende demokrasie tot } \\
\text { deelnemende demokrasie }\end{array}$ & $\begin{array}{l}\text { 7. Die toenemende gebruik van intulsie } \\
\text { en visie }\end{array}$ & 7. Die dekade van die vrou in leierskap \\
\hline 8. Hierargied tot netwerke & $\begin{array}{l}\text { 8. Die wanaanpassing tussen die opvoed- } \\
\text { kundige stelsel en die behoeftes van die } \\
\text { nuwe informasiegemeenskap }\end{array}$ & 8. Die eeu van biotegnologie \\
\hline 9. Noord tot Suid & $\begin{array}{l}\text { 9. Die toename in die belaggrikheid van } \\
\text { korporatiewe gesondheidstrydpunte }\end{array}$ & $\begin{array}{l}\text { 9. Die religieuse herlewing van die nuwe } \\
\text { millenium }\end{array}$ \\
\hline 10. Of dit/of dat tot yeelvuldige opsies & $\begin{array}{l}\text { 10. Die waardes van die generssie wat } \\
\text { gebore is tussen } 1946 \text { en } 1964\end{array}$ & 10. Die triomf van die individu \\
\hline
\end{tabular}

\subsubsection{Die verandering vanaf sentralisasie tot desentralisasie}

Mag vloei van onder af na bo. Gedesentraliseerde eenhede kry meer outonomie en mag, en gesagstyl word ook meer selfgeldend van aard. Desentralisasie impliseer ook dat daar meer sentrums is en gevolglik meer geleenthede en keuses vir individue. 


\subsubsection{Die verandering vanaf institusionele hulp na selfhulp}

Gemeenskapsgroeperings neig om groot administratiewe, oorgereguleerde agentskappe te vervang. Die privaatsektor raak meer en meer betrokke in 'n verskeidenheid van dienste op onder andere diverse terreine soos gesondheid, opvoeding en ontspanning. Dit verteenwoordig ' $n$ verskuiwing vanaf 'n bestuurs- tot 'n entrepreneuriese gemeenskap.

\subsubsection{Die verandering vanaf 'n verteenwoordigende tot 'n deelnemende demokrasie}

Hierdie is ' $n$ tipiese Amerikaanse politiese mega-tendens, maar die implikasies is van algemene belang. Dit word gesien in verbruikerswese, aandeelhouers se houdings, werkers se regte, deelname en leierskapstyle.

\subsubsection{Die verandering vanaf hierargieë tot netwerkvorming}

Netwerke bestaan om inligting uit te ruil, om die gemeenskap te verander, om produktiwiteit en werksomstandighede te verbeter en om beskikbare bronne te deel. Netwerke kan gesien word as die voorsiening van ' $n$ vorm van kommunikasie en interaksie wat geskik is vir die energie-skaars en inligtingryke toekoms. Horisontale skakeling word daargestel om onder andere nuwe kennis te genereer en nuwe entrepreneurskap en besigheidstipes toe te laat om te ontstaan.

\subsubsection{Die verskuiwing van aktiwiteite in die VSA}

Hierdie is ook 'n besondere Amerikaanse ontwikkeling wat betrekking het op die geleidelike hertoedeling van mense, bronne, indiensname en welvaart gedurende die laaste dekades. Sodanige verskuiwings vanaf die noordelike na die suidelike state skep ontwrigtings, maar tergelykertyd ook nuwe geleenthede omdat nuwe stede vinnig ontwikkel.

\subsubsection{Die verandering vanaf die enkel opsie tot veelvuldige opsies}

Die gemeenskap verlaat geleidelik die weg van die tradisioneel-eenvormige na dié van diversiteit. Die eenvormige massagemeenskap het versplinter in baie groepe mense met 'n wye verskeidenheid van waardes, voorkeure en smake: dit het 'n markgesegmenteerde en markgedesentraliseerde gemeenskap geword. 
Volgens Naisbitt beskryf hierdie tien mega-tendense 'n ewolusionêre toestand wat in baie dele van die Amerikaanse gemeenskap waargeneem kan word. Die vraag is of hierdie beskrywing toegepas kan word op Suid-Afrika.

Ek is van mening dat Naisbitt se uitgangspunte ook direk toegepas kan word deur nieAmerikaanse lesers. Bykans alles wat Naisbitt in sy publikasie stel, kan op een of ander wyse toepasbaar gemaak word op ander lande (Naisbitt, 1982:xxix).

3.2 Die 'heruitvinding' van die onderneming (Re-inventing the corporation, 1985)

Naisbitt het, alhoewel nie in die sin wat vroeër in die artikel vermeld is nie, vanaf 'n makrovlak na mikro-ekonomiese faktore beweeg en tien addisionele stellings gemaak. Hierdie stellings het ten doel om die funksionering van die toekomstige onderneming te herdefinieër en is afgelei van mega-tendense en sosiologiese waarnemings soos byvoorbeeld die toenemende rol van die vrou in die arbeidsmark en bestuur.

3.2.1 Die verskuiwing in strategiese bronne van 'n industriēle na 'n inligtings. gemeenskap

Nuwe sleutelbronne vir die onderneming is inligting, kennis en kreatiwiteit wat belangriker as kapitaal is. Dit impliseer dat 'n kritiese suksesfaktor in die toekoms die voorkeuraanwending van menslike hulpbronne sal wees.

\subsection{2 'n Verkopersmark en die nuwe mededinging vir die beste werknemers}

'n Projeksie wat gemaak is, is dat die arbeidsmark na 1990 in die VSA stram sal word met ' $n$ verskuiwing van ' $n$ kopersmark tot ' $n$ verkopersmark. Dit versterk stelling 2.1 met betrekking tot (skaars) menslike hulpbronne.

\subsubsection{Die inkorting van middelbestuur}

Die tegnologie van die rekenaar is steeds besig om te groei en uit te brei na nuwe velde. Dit impliseer 'n daling in die behoefte vir middelbestuur. 


\subsubsection{Die kontinuerende entrepreneuriese revolusie}

Innovasie en ondernemerskap sal die belangrikste vereistes vir sukses in die toekoms wees, met die gevolg dat die behoefte sterk na vore kom om toepaslike motiverings- en vergoedingsisteme te ontwikkel.

\subsubsection{Die opkoms van 'n nuwe arbeidsmag}

Die huidige arbeidsmag is jonger, beter opgelei en maak toenemend gebruik van vroue wat toetree tot die arbeidsmag. Hierdie faktore bring mee dat die aard van die werkplek verander om die nuwe werker te akkommodeer.

\subsubsection{Die demografiese revolusie van die werkende vrou}

Die vrou is besig om ' $n$ toenemend-belangrike rol in die huishouding en op die arbeidsmark te vervul. Dit sal nuwe gewoontes, gedrag en die werkverrigtingwyses van ondernemings impliseer, onder andere vanweë die dubbele rol wat die werkende vrou gewoonlik moet vervul.

\subsubsection{Die toenemende gebruik van intuīsie en visie}

Ondernemingsbestuur sal meer en meer intuïtiewe visionêre denkmetodes gebruik omdat dit blyk dat rasionaliteit en kwantitatiewe beplanning moeiliker sal wees om in 'n toenemende komplekse wêreld toe te pas.

3.2.8 Die wanaanpassings tussen die opvoedkundige stelsels en die behoeftes van die nuwe inligtingsgemeenskap

Dit blyk dat die opvoedkundige stelsels in die wêreld nie altyd beantwoord aan die behoeftes van die gemeenskap nie. Veranderinge gaan verder plaasvind ten opsigte van die opvoedkundige behoeftes en metodes en om dit te akkommodeer, sal ondernemings betrokke moet raak by samewerkingsooreenkomste soos wat alreeds die geval is met alliansies tussen ondernemings en universiteite. Konseptuele denke sal nodig wees om nuwe modelle vir sodanige samewerking daar te stel. 
3.2.9 Die toename in die belangrikheid van korporatiewe gesondheidsdienste

Om die onderneming se belangrikste bron, naamlik sy mense te bewaar, sal insette in verskeie vorms deur ondernemings self gelewer moet word om op 'n korporatiewe vlak gesondheidsdienste en programme daar te stel. Op dié wyse sal die kwaliteit van die arbeidsbron behou kan word.

3.2.10 Die waardesisteem van die generasie wat tussen 1946 en 1964 gebore is

Nuwe waardes sal geleidelik die waarde-sisteme van vroeër vervang. Hierdie nuwe waardes sal onder andere in aspekte soos outonomiteit, ondernemerskap, sosiale liberalisme en ekologiebewustheid weerspieël word.

\section{Samevattend}

Wanneer die invloed van Naisbitt se eerste twee publikasies ontleed word, word die volgende as kenmerke van die toekomsonderneming onderskei: die nuwe onderneming word gekenmerk deur meer kennis en kreatiwiteit, 'n meer buigbare struktuur (netwerke, filiale, entrepreneuriese projekte), minder steun op formele outoriteit en meer op motivering en selfverwesenliking. Ook speel strategiese visie eerder as formele beplanning ' $n$ rol, is daar groter aanvaarding van interaksies tussen die gemeenskap en die onderneming en word die rol van die vrou toenemend belangrik.

\section{$3.3 \quad$ Megatrends $2000(1990)$}

\subsubsection{Die opkomende wêreld-ekonomie van die negentigerjare}

Daar is 'n toenemende tendens tot een wêreld-ekonomie. Die ekonomiese kragte van die wêreld is besig om oor nasionale grense heen te beweeg met as resultaat groter demokrasie, meer vryheid, meer handel, meer geleenthede en groter welvaart.

\subsubsection{Die Renaissance in die kunste}

Volgens Naisbitt vind daar 'n fundamentele en revolusionêre verskuiwing in vryetydsen bestedingsprioriteite plaas. Sport as die gemeenskap se primêre ontspanningsaktiwiteit sal geleidelik deur die kunste vervang word. 


\subsubsection{Die opkoms van die vrye-mark sosialisme}

Die wêreld is besig met 'n duidelike verskuiwing van ekonomieë wat deur regerings bedryf word tot ekonomieë wat weer op hul beurt gestu word deur markkragte. Vryemark sosialisme is die oorgangsfase vir sosialistiese lande soos hulle die een-entwintigste eeu ingaan.

\subsubsection{Wêreldlewenstyle en kulturele sosialisme}

Hoe meer homogeen mense se lewenstyle word, hoe meer wend hulle hul tot die dieper waardes van byvoorbeeld godsdiens: hierdie tendens is waarskynlik 'n reaksie teen die hedendaagse gelykmakingsproses. In die godsdiens kan die mens nog sy uniekheid as individu beleef. Namate die mens se strewe na 'globalization' toeneem, sal hy ook toenemend sy tradisies koester en probeer bewaar.

\subsubsection{Die privatisering van die welvaartstaat}

Deur mense meer mag te gee om hulle lewens te reguleer, vind daar 'n globale verskuiwing van 'n welvaartstaat na privaatbesit plaas.

\subsubsection{Die opkoms van die Pacific Rim}

Hierdie gebied is besig om die tydperk van die vinnigste ekonomiese uitbreiding in die geskiedenis te ondergaan. Die belangeverskuiwing vanaf die Amerikaanse en Europese gebiede is nie net ekonomies nie maar ook kultureel van aard en word versterk deur die onderneming om opvoedingsgeriewe daar te stel.

\subsubsection{Die dekade van die vrou in leierskapposisie}

Nie alleen sal die leierskap van groot ondernemings in die toekoms tot 'n groot mate in die hande van vroue wees nie, maar hulle sal ook die informasie-gemeenskap domineer as werkers, professionele persone en entrepreneurs.

\subsubsection{Die dekade van biologie}

In plaas daarvan om die mens se probleme vanuit die fisika te benader en te probeer 
verklaar, word deesdae gekonsentreer op die biologie. Dit word al meer duidelik dat die biotegnologie die kern van die mens se toekoms gaan word.

\subsubsection{Die godsdienstige herlewing van die nuwe millenium}

Aan die begin van die derde millenium is daar ongetwyfeld tekens van 'n wêreldwye multidimensioneie godsdienstige herlewing. Wanneer die mens worstel met verandering, intensifiseer die behoefte aan geloof.

\subsubsection{Die triomf van die individu}

Die negentigerjare word gekenmerk deur 'n nuwe respek vir die individu as die basis van die gemeenskap en die basiese eenheid van verandering. Die triomf van die individu kondig die totnietgaan van die kollektiewe aan. Toegepas op die huidige situasie kan dit onder andere die volgende beteken: die mens word weer méer as 'n nommer; in die kleinsakeonderneming het hy individualiteit, word hy as mens geken.

\section{TOEPASSINGS OP ENTREPRENEURSKAP EN KLEINSAKEONDER- NEMINGS}

Die vraag wat nou ontstaan is die relevansie van so 'n analise vir Suid-Afrika en kleinsakeondernemings.

Dit is duidelik dat 'n mens hier te doen het met die 'sagter' kant van die wetenskap. Vooruitskatting, veral sosiale vooruitskatting, is 'n bruikbare stuk gereedskap maar die geldigheid daarvan word beperk deur baie faktore. Naisbitt se benadering is onderhewig aan 'n redelik ongeldige mengsel van (waargenome en statisties-gedemonstreerde) feite, aannames, norme en selfs (waarskynlik persoonlike) voorkeure. Dit moet egter beklemtoon word dat sy bydraes gesien moet word as 'n inset in die globale persepsie wat bestuur moet vorm met betrekking tot 'n bepaalde visie van die toekoms. So 'n visie is 'n deurlopende ontwikkelende mengsel van ervaring van die huidige en verlede, intuïsie, maar ook van begripsvorming.

Naisbitt se analise bring ' $n$ aantal aspekte vir die toekoms van kleinsakeondernemings na vore. Een manier om die probleem te behandel is om daarop te let dat sy werke in vier duidelike kategorieë val, met'n mate van oorvleueling byvoorbeeld Megatrends (6),(8),(9) en (10). Die kategorieë is soos in tabel 2 hieronder. 
Die invloed van toekomstendense op entrepreneurs en kleinsakeondememings

Tabel 2

Kategorisering van hoofstukke in Naisbitt se boeke

\begin{tabular}{|l|l|l|l|}
\hline $\begin{array}{l}\text { Bron } \\
\text { Kategorie }\end{array}$ & Megatrends & $\begin{array}{l}\text { Re-loventlog the } \\
\text { corporation }\end{array}$ & $\begin{array}{l}\text { Megatreads } \\
2000\end{array}$ \\
\hline $4.1 \quad$ Tegnologiet en tegniese stelsels & 2,3 & & - \\
4.2 Ekonomie & 3 & - & $1,3,5,6$ \\
$4.3 \quad$ Kulturele, sosiale, godsdienstige politieke & $5,6,7,8,9,10$ & 6,9 & $2,4,6,7,8$, \\
$4.4 \quad$ Bestuur en organisesie & $4,5,6,8,9$ & $1,2,3,4,5,6,7,8,9,10$ & $7,8,10$ \\
\hline
\end{tabular}

Vir elk van die kategorieë (4.1 - 4.4) word gepoog om die betekenis daarvan vir entrepreneurs en kleinsakeondernemings te gee en te sien tot watter mate hulle besondere kenmerke (sterk en swak punte) hierdie implikasies mag omskep in nuwe geleenthede of bedreigings.

\subsection{Tegnologieẽ en tegniese stelsels}

Die opkoms van nuwe tegnologieë soos die laser, biotegnologie en nuutsaamgestelde materiale, sal 'n hele aantal kragte vrystel wat soos skokgolwe sal inwerk op 'n groot aantal kleinsakeondernemings. Die volgende aspekte van sodanige kragte kan in berekening gebring word:

\subsubsection{Die invloed op kostestrukture en verandering in mededingende posisie}

Nuwe tegnologieë is oor die algemeen duur terwyl huidige tegnologieë dikwels gerasionaliseer of vervang moet word. Dit mag op grond van verskeie redes tot nadeel van die kleinsakeonderneming strek: tekort aan ontwikkelingsfondse, dikwels 'n bepaalde houding van versigtigheid met betrekking tot verandering in toerusting en in prosesse, dikwels onvoldoende opleiding.

'n Faktor wat mag lei tot die vermindering van hierdie erkende nadeel is dat nuwe tegnologieë, alhoewel duur, dikwels aangepas word vir relatief kleinskaal-kapasiteite of dat dit verkry word op 'n modulêre basis. Op dié wyse word die aanpassing by verandering vergemaklik. Aan die negatiewe kant moet egter daarop gewys word dat 
nuwe tegnologieë in die meeste kleinsakesektore die mededingende voordele van die bemeestering van handvaardighede (byvoorbeeld in handwerkbedrywe) verminder in vergelyking met meer gesofistikeerde, meer intellektuele vorme van produksie. (Vergelyk rekenaarprogramme soos C.A.M., C.A.D., e.a.)

Verder moet daarop gewys word dat die invloed van kostevervanging (masjien teenoor mens) waarskynlik negatief vir die kleinsakeonderneming is.

\subsubsection{Invloed op markte}

Een kenmerk van nuwe tegnologieë is die uitkring van die invloed daarvan, byvoorbeeld inligtingstegnologieë bring nie alleen nuwe markte tot stand nie, maar dit word ook beliggaam in bestaande produkte.

Hierdie uitkringende invloed is waar van produkte (elektronika in motors), maar ook van dienste. Tot die mate waarin kleinsakeondernemings dit oor die algemeen moeilik mag vind om onmiddellik aan te pas by nuwe tegnieke, sal hulle gebruiklike vertroue op goed-beheerde en vooraf bepaalde posisies (niches) moontlik geskaad word.

As gevolg van die opkoms van nuwe produkte deur die kleinsakeondernemings self, kan, in teenstelling tot die negatiewe belewing van niches, 'n meer optimistiese siening waargeneem word. 'n Tipiese voorbeeld is die Silicon Valley-sindroom waarvan replikas nou in sommige Europese lande ontstaan. Versigtigheid moet egter hier aan die dag gelê word omdat dit belangrik is om tussen verskillende verskynsels te onderskei.

Daar mag in Suid-Afrika suksesvolle hoë-tegnologie kleinsakeondernemings wees, nie alleen op die gebied van die elektronika nie, maar ook ten opsigte van programmatuur, laboratoriums en ander gebiede, maar dit verteenwoordig 'n baie klein persentasie van die Suid-Afrikaanse kleinsakepopulasie. Meer belangrik, in terme van groei, is die opkoms van klein ondernemings wat indirek voordeel trek uit die uitbreiding van hoë tegnologie. Birch (1981) wys daarop dat die belangrikste bydrae tot indiensname en skepping van kleinsakeondernemings gemaak is deur sulke aktiwiteite soos onderhoud, hersteldienste en konsultasiedienste in teenstelling tot sektore soos sekuriteit, fastfoods en ander sektore waarvan die skepping meer gekoppel word aan kulturele veranderinge.

In Suid-Afrika lê die skep van kleinsakeondernemings meer op die terrein van die informele sektore in produksie, distribusie en dienste (vgl. Havenga, 1990:12-14 vir 'n gedetailleerde uiteensetting van tipe ondernemings; Havenga, 1988:54-65 ten opsigte van belangrikheid tot indiensname). 
4.13 Invloed op die verhouding tussen kleinsakeondernemings en groter ondernemings

Kleinsakeondernemings vertolk tradisioneel 'n belangrike rol in die industriële produksieproses in die vorm van subkontrakteurs. Hier is veral Japan 'n sprekende voorbeeld. Gegewens dui daarop dat die afhanklikheidskoers op subkontraktransaksies van medium- en kleinsakeondernemings vir die vervaardigingsindustrie $35,5 \%$ in Japan was, met vervoertoerusting so hoog as $73,7 \%$. (Kosaka, 1990:43; vgl. ook Ogawa, 1989:16.)

In Europa was die gemiddelde persentasie subkontrakterende medium- en kleinsakeondernemings in die kledingbedryf in sewe lande $41,4 \%$ met die Verenigde Koninkryk so hoog as $59,1 \%$. Subkontrakterende ondernemings volgens tipe entrepreneurs in Wes-Europa het onderskeidelik 50,0\% vir pionier-entrepreneurs, 37,8\% all-rounders, $39,6 \%$ routineers en vir organiseerders $36,1 \%$ beloop (Schmidt, 1990:7).

Omdat Suid-Afrika nog nie op die industriële en tegnologiese vlak soos bogenoemde lande funksioneer nie, kan aanvaar word dat die aspek van subkontraktering by kleinsakeondernemings nog relatief laag sal wees.

Nuwe tegnologieë, omdat dit neig na meer soepelheid, sal massaproduksie verminder en dit vervang met kleiner geïntegreerde produksie-eenhede. Terselfdertyd neig groot ondernemings om te herbesin oor die mak of koop-opsie, ten einde hulle eie betrokkenheid in 'n hele aantal produktiewe aktiwiteite so ver as moontlik te verminder. Die dubbele invloed vir die klein firmas is dat hulle die geleentheid kry om dié aktiwiteite oor te neem, maar terselfdertyd word ook toegelaat dat hulle afhanklikheid van die groot ondernemings uitermate toeneem.

\subsection{Ekonomie}

Mega-tendense (hoofstuk 3) en mega-tendense 2000 (hoofstukke 1,3,5 en 6) beklemltoon onder andere die groeiende tendense van die werreldhandel; gevolglik het die eksterne uitvoerkomponent wat moontlik sal voortduur toegeneem in bykans alle lande, asook in Suid-Afrika. Die vraag wat ontstaan, is tot welke mate dit kleinsakeondernemings in Suid-Afrika sal beïnvloed.

Indien daar gekyk word na invoere, sal kleinsakeondernemings die groeiende mededinging van die buiteland in aanmerking moet neem. Natuurlik sal sekere sektore, meer spesifiek dienste, minder geraak word. Oor die geheel gesien, kan groter onstabiliteit en meer onsekerheid ontstaan vir klein ondernemings, veral daardie 
ondernemings wat sterk funksioneer op tegnologiese gebied asook op die gebied van tekstiele, skoeisel en algemene elektronika. Ironies genoeg het boikotte en sanksies juis 'n groot mate van beskerming aan kleinsakeondernemings gebied en interne ontwikkeling tot gevolg gehad het. Die opheffing van sanksies sal die Suid-Afrikaanse ekonomie 'n groter deel van die wêreld-ekonomie maak.

'n Meer onbevange ekonomie sal ongetwyfeld groter uitvoere met groter geleenthede bied vir Suid-Afrikaanse entrepreneurs en kleinsakeondernemings wat kan aanpas by wêreldmarktoestande. As voorbeeld kan gestel word dat volgens gegewens beskikbaar (Stratos Group, 1990:65) het 60,7\% van die medium- en kleinsakeondernemings in 1985 in Wes-Europa 'n persentasie van tot $24 \%$ van hulle verkope uitgevoer. Verder het $89,5 \%$ van hierdie tipe ondernemings tot $74 \%$ van hul verkope uitgevoer.

Ander ekonomiese faktore verwys onder andere na die invloed van werkloosheid. Interessant is die feit dat die toename in werkloosheid en die relatiewe hoë vlak daarvan asook groter deregulering aanleiding gegee het tot die totstandkoming van kleinsakeondernemings in Suid-Afrika (Havenga, 1990:7-10). Gedeeltelik kan dit ook toegeskryf word aan die herkanalisering van die arbeidsmag vanaf die groot ondernemings na die kleiner ondernemings, deels as 'n resultaat van eersgenoemde se strategie om arbeidskoste te verminder asook die rasionalisasieprosesse wat aan die orde van die dag is. Privatisering van staatsondernemings met die gevolglike afdanking van personeel het beslis ook 'n bydrae tot hierdie tendens gelewer.

Die omvang van hierdie privatiseringsproses is natuurlik wêreldwyd en die skepping van kleinsakeondernemings word deur Naisbitt (1990:154-177) as 'n resultaat daarvan geïllustreer. Witskrifte van owerheidsweë in Suid-Afrika bied ook goeie agtergrond oor die privatiseringsproses en kleinsakeondernemings (vgl. P.C. 4/1985 en WPG 1987).

'n Verdere verklaring kan wees dat swak ekonomiese toestande in Suid-Afrika vir hierdie privatiseringsproses verantwoordelik is. Handy (1984:41-52) wys daarop dat 'n resessie mense motiveer om nuwe besighede te begin en nuwe vorme van werk daar te stel. Hierdie nuwe vorme van werk wissel vanaf mauve, grey en black economy en word deur klein besighede opgeneem. In Suid-Afrika was die ontwikkeling van die informele sektor kenmerkend van die swak ekonomiese toestande die afgelope aantal jare (Havenga, 1990:12-14; Kirsten, 1988:251-257).

In die lig van die nuwe politieke bedeling in Suid-Afrika sal die groei in kleinsakeondernemings, hetsy op formele of informele vlak, 'n belangrike deel van die ekonomiese ontwikkeling uitmaak. 


\subsection{Kulturele, sosiale, godsdienstige en politieke aspekte}

Dit is waarskynlik waar Naisbitt se analise die mees gedagte-prikkelend is. Die nuwe kulturele en sosiale tendense wat hy beskryf is oor die algemeen baie gunstig vir die entrepreneur en klein onderneming. Die nuwe lewenstyle en waardes beklemtoon daardie faktore waar die kleinsakeonderneming 'n mededingende voordeel het. Hierdie voordeel is onder andere geleë in aspekte soos die onmiddellikheid en beskikbaarheid van diens aan klante, die moontlikheid van vinnige besluitneming (versus 'n burokratiese handelswyse) en die groter mate van aanpasbaarheid. Hierby moet ook nog gestel word dat hierdie mega-tendense sekere verskuiwings in verbruikersgedrag veronderstel - iets wat baie gunstig mag wees vir kleinsakeondernemings. Aspekte soos vryetyd, diskresionêre tyd, fleksielewens en korter werksure en -lewe is hier ter sprake (Handy, 1984:61, 158, 163 en 180), en sal veral 'n invloed uitoefen sover dit dienste betref. Miskien is een van die belangrikste uitvloeisels hiervan dat as diversiteit 'n primêre tendens word, die kreatiewe goedaangepaste klein onderneming voordeel sal trek uit die veelvuldige geleenthede.

Die probleem vir kleinsakeondernemings en vir nuwe entrepreneurs is daarom om te bewys dat hulle skeppend en goed aangepas is om voordeel uit hierdie tendense te kan trek. Dit skyn asof die kleinsakeonderneming in Suid-Afrika in die lig van bogenoemde tendense ' $n$ besliste rol het om te speel. Die inwerkingstelling van hierdie tendense kan geaktiveer word deur onderlinge samewerking, spesiale skakeling met groot ondernemings en in baie gevalle deur te konsentreer op die kommersiële kant van innovasie.

Die groter prominensie van die godsdienstige het tot gevolg dat die etiese aspekte sedert die begin van die tagtigerjare in Suid-Afrika in 'n groter mate benadruk word. In die praktyk is dit veral gekenmerk deur die aanvaarding van groter sosiale verantwoordelikheid deur die onderneming. Vergelyk in hierdie verband 'n studie ten opsigte van sosiale verantwoordelikheid deur die kleinsakeonderneming (Visagie, 1987).

\subsection{Organisasie en bestuur}

In sy boek Re-inventing the corporation beklemtoon Naisbitt 'n aantal faktore wat die bestuur in die toekoms sal kenmerk. Skeppingsvermoë en kennis, nuwe werkmetodes, die toenemende rol van intuïsie en visie, groei van elektroniese dataverwerking en 'n gees van entrepreneurskap sal aan die orde van die dag wees mits die onderneming dinamies en goed bestuur word. Al hierdie aspekte is ook van toepassing op die kleinsakeonderneming. 
'n Belangrike gevolgtrekking is dat indien daar 'n uitbreiding en ontwikkeling van hierdie nuwe bestuurskenmerke sal wees, alleen die mees dinamiese entrepreneurs en kleinsakeondernemings in 'n posisie sal wees om voordeel te trek uit hierdie verandering. Te dikwels word die bestuur van klein ondernemings in Suid-Afrika, soos ook in ander lande, gekortwiek deur ' $n$ ingesteldheid van roetine-aktiwiteite en ontoepaslike leierskapstyle. Ondoeltreffende leierskapstyl is dikwels ook die resultaat van ouderdom en die oorskakelingsprobleem van bestuurstyl deur opvolgers in die onderneming.

Alhoewel daar deur Naisbitt gewys word op die verandering in die arbeidsmark van 'n kopers- na 'n verkopersmark, sal daar ten spyte van die nuwe arbeidsbesparende tegnologieë 'n skaarsheid van geskikte arbeid wees. In Suid-Afrika is dit egter nie die geval nie omdat daar 'n ooraanbod van ongeskoolde, half-geskoolde en, selfs in sekere rigtings, van geskoolde arbeid is. Verder is daar vanweë die werkloosheid 'n toenemende tendens van toetrede tot die informele kleinsakesektor - iets wat nog verder gestimuleer word deur die proses van deregulering.

Uiteraard is dit noodsaaklik om daarop te let dat variasies in bestuursontwikkeling en -opleiding van bestuur van die informele en formele kleinsakeondernemings ' $n$ vereiste is. Sakeskole aan universiteite en kleinsake-adviesburos gee alreeds aandag aan bestuursopleiding via besondere kursusse in tegnologiebestuur en innovasie, entrepreneurskap en kleinsakebebestuur en ander doelgerigte bestuurskursusse.

\section{SLOTOPMERKINGS}

Dit blyk dat kragte wat tans aan die werk is tot 'n groot mate teenstellend van aard is. Die vraag kan gestel word of entrepeneurskap om hierdie rede, synde 'n utopia, laat vaar moet word. Is toekomstendense en entrepeneurskap moontlik te moeilik om te ontleed, te geneig tot onsekerhede? Soos somtyds deur deskundiges op die gebied van strategie gestel word: om niks te doen is ook 'n strategie, of 'n onderneming kan 'n strategie hê sonder om dit te besef (Thompson, 1990:79).

Daarom kan ook gestel word dat daar 'n behoefte bestaan vir voorbereiding en opleiding om gedagtes en idees uit te ruil, statistiek en data te versamel, ervarings te vergelyk, opsies te bespreek en motiverings en aksies te skep. Op dié wyse kan entrepreneurskap en kleinsakeondernemings ontwikkel en bevorder word. Besondere aandag word aan hierdie prosesse bestee deur netwerkvorming en -funksionering (vgl. Donckels, 1989; Cromie \& Carson, 1991; Monsted, 1991).

Miskien is die belangrikste gevolgtrekking relatief eenvoudig. Die groot hoeveelheid

Koers 56(4) 1991:591-609 
kragte wat in die toekoms van entrepreneurs en kleinsakeondernemings in Suid-Afrika werksaam is, sal besliste invloed op die globale situasie van die sektor hê. Dit wil voorkom asof daar 'n redelike balans tussen bedreigings en geleenthede bestaan. In elk geval sal aanvaar moet word dat alleen die klein sakeondernemings wat op die mees effektiewe wyse bestuur word, kan oorleef en groei. Hierdie ondernemings sal deeglik moet kennis neem van toekomstendense en dit kan geskied deur twee benaderings soos Wilson dit stel (Thompson et al., 1990:92). Toekomsprojeksies kan gemaak word deur enersyds die makro-omvang van langtermyntendense te ontleed. Andersyds kan berekeninge gemaak word deur die ontwikkeling van alternatiewe scenarios vir ' $n$ tydperk van 10 tot 15 jaar vorentoe en deur ook terugwaarts berekeninge te doen deur 'n proses van deduktiewe beredenering. Sodoende kan hipoteses ontwikkel word met betrekking tot die implikasies vir die onderneming vir die onmiddellike toekoms.

\section{BIBLIOGRAFIE}

COATES, J.F, \& JARRATT, J. 1989. What futurists believe. Maryland : Lomond Publications, Inc.

CROMIE, S. \& CARSON, D. 1991. Marketing information: Its collection and utilization by small firms. Proceedings of the 36th ICSB Conference, June 24-26 1991. Vienna, Austria. Vol. 3, pp. 51-58.

DONCKELS, R. 1989. Unternehmensgründung: Eine Herausforderung für Politik, Training und Führung. Intemationales Gewerbearchiv. Sonderheft 3. Berlin : Duncker \& Humbolt. pp, 42 47.

HANDY, C. 1984. The future of work. Worcester, Britain : Billing \& Sons.

HAVENGA, J.J.D. 1988. Small business employment creation and costs. Joumal of Small Business and Entrepreneurship, 5(4):54-65.

HAVENGA, J.J.D. 1990. Die Deregulierung und ihre Auswirkungen auf die Entwicklung des Unternehmertums. Intemationales Gewerbeanchiv, 39(2):109-120.

KIRSTEN, M. 1988. A quantitative perspective on the informal sector in Southern Africa. Development Southem Africa, 5(2):251-257.

KOSAKA, T. 1990. Cont rol mechanism in the Japanese subcontracted division-of-work system and the emergence of network-type organizational structure. The Study of Business and Industry, 7:2148.

MONSTED, M. 1991 Different types of regional networks: Methodological considerations. Proceedings of the 36th ICSB Conference, June 24 - 26 1991. Vienna Austria. Vol. 3, pp. 94 - 104.

NAISBITT, J. 1982. Megatrends: Ten new directions transforming our lives. New York : Warner Books, Inc.

NAISBITT, J. \& ABURDENE, P. 1985. Re-inventing the corporation. New York : Warner Books.

NAISBITT, J. \& ABURDENE, P. 1990. Mega-trends 2000: Ten new directions for the 1990's. New York : William Morrow \& Co. Inc.

OGAWA, E. 1989. Organisation und Finanzierung des Strukturwandels der Wirtschaft in Japan und in der Bundesrepublik Deutschland. Herausgegeben von Karl-Heinz Schmidt. Paderborn : Universitāt - Gesamthochschule.

P.C. 4/1985. A strategy for small business development and for deregulation. Cape Town : Government Printer.

SCHMIDT, K-H. 1990. International comparison of subcontracting business in West European countries and Japan. The Study of Business and Industry, 7:1-19. 
STRATOS GROUP. 1990. Stratcgic orientations of small European businesses. London : Avebury, Aldershot.

THOMPSON, A.A., FULNER, W.E. \& STRICKLAND, A.J. 1990. Readings in strategic management. Homewood, Illinois : Richard C. Irwin Inc.

WPG. 1987. White paper on privatisation and deregulation in the Republic of South Africa. Pretoria Government Printer.

VISAGIE, J. 1987. Die sosiale verantwoordelikheid van kleinsakeondernemings met spesiale verwysing na enkele vervaardigingsondernemings in Potchefstroom. Potchefstroom. (Verhandeling (M.Com.) - PU vir CHO.) 
